\title{
3D And 2D RNA Structure Prediction Of The BRCA2 Gene And Its Silencing RNA In The Breast Cancer
}

\author{
Ryan Widjaja1, Arli Aditya Parikesit ${ }^{*}$, Rizky Nurdiansyah ${ }^{1}$ \\ 1Department of Bioinformatics, School of Life Sciences, Indonesia International Institute for Life \\ Sciences, Jl. Pulomas Barat kav.88 Jakarta 13210 \\ E-mail: arli.parikesit@i3l.ac.id
}

\begin{abstract}
Abstrak
Kanker payudara adalah salah satu penyakit yang paling berbahaya bagi wanita. Sampai sekarang, perawatan yang tersedia untuk kanker payudara adalah kemoterapi dan radioterapi dengan kekurangan dan efek sampingnya. Dalam hal ini, metode biologi molekuler baru telah dirancang untuk mempelajari mekanisme molekuler kanker payudara. Ditemukan bahwa gen BRCA2 memainkan peran penting dalam kanker payudara, asalkan mutasi terjadi. Dengan demikian, prosedur komputasi dirancang untuk membubuhi keterangan data molekuler. Tujuan dari penelitian ini adalah untuk menentukan apakah pendekatan bioinformatika dapat menyediakan jaringan gen, simulasi molekuler, dan informasi metabolomik komputasi untuk melepaskan hubungan antara mutasi gen BRCA2 dengan perkembangan kanker payudara. Metode ini menggunakan alat simulasi molekuler untuk memahami interaksi biokimia gen BRCA2 dengan gen onkogenik lainnya. Terakhir, alat docking molekuler dirancang untuk memberikan informasi interaksi molekuler. Pada akhirnya, struktur 3D dan 2D dari biomarker dapat dirancang dan disiapkan sebagai cetak biru untuk desain obat. Dapat diimplikasikan bahwa Computer-Aided Drug Design (CADD) yang berbasis pada alat transkriptomik silico dapat memberikan informasi yang lengkap mengenai peran pasti gen BRCA2 dalam perkembangan kanker payudara dan mendapatkan pengetahuan tentang pengembangan obat, terutama mengenai desain siRNA. Dampak klinis dari penelitian ini hanya dapat diukur setelah percobaan laboratorium basah dilakukan untuk memvalidasi hasil pendekatan komputasi.
\end{abstract}

Kata kunci: BRCA2; Bioinformatika; Kanker Payudara; Simulasi Molekuler; Jaringan Gen

\begin{abstract}
Breast cancer is one of the most threatening diseases for women. It is found that BRCA2 gene plays a significant role in breast cancer, provided that mutations occurred. The objective of this study is to determine whether the bioinformatics approach could provide the gene networking, molecular simulation, and computational metabolomics information to shed the relation between BRCA2 gene mutation with breast cancer progression. The methods are utilizing molecular simulation tools to comprehend the biochemical interaction of BRCA2 gene with other oncogenic genes. Lastly, the molecular docking tool is devised to provide the molecular interactions information. It could be implied that the Computer-Aided Drug Design (CADD)-based in silico transcriptomics tools could
\end{abstract}


provide the fine-grained information on the exact role of BRCA2 gene in the progression of breast cancer. The clinical impact of this study could only be measured after the wet laboratory experiment is conducted to validate the computational approach results

Keywords: BRCA; Bioinformatics; Breast Cancer; Molecular Simulation; Gene Networking

\section{Introduction}

Breast cancer is the most common cancer among women. It affects more than 1.5 million women each year and causes the greatest number of cancer-related death among women. About 570,000 women died from breast cancer in 2015, which equals to approximately $15 \%$ of all cancer deaths among women. Breast cancer rates are increasing globally, as the incidence rates is various ranging from around 19.3 per 100,000 women in Eastern Africa and 89.7 per 100,000 women in Western Europe. Moreover, it is concerning as in the developing countries, the survival rates is just below 40\% (Parikesit et al., 2018a; Surveillance Epidemiology and End Results Program, 2019; WHO, 2015) .

The current treatments for breast cancer include surgery, radiation therapy, chemotherapy, and hormone therapy and are generally based on the type and stage of the breast cancer. If the breast cancer is still small and not metastasized, then the cancer can be removed by surgery. If the cancer has metastasized, then the common treatment is radiation therapy and/or chemotherapy. Radiation therapy and chemotherapy use high-energy rays (such as x-ray) and drugs, respectively, for destroying cancer (Cleator et al., 2007; Spicer, 2005).

Many scientists around the world are still doing lots of research on breast cancers. Some of the current areas of research of breast cancer include: the causes of breast cancer; new ways to prevent breast cancer; testing new drug therapies; new methods to detect cancer; and many other topics. For example, there is a research about the possibility of using the volatile organic compounds (VOCs) from human breath as biomarkers for breast cancer (Bonofiglio et al., 2016; Cherigo et al., 2015; Goncalves et al., 2014; Wu et al., 2012).

Some of the current research on breast cancer involves the use of transcriptomics to find some new methods to detect and treat the breast cancer. One of the common cause of breast cancer is the mutation in BRCA2 gene (Hedau et al., 2015; Petrovic et al., 2017). It is also known that the mutations in the BRCA2 gene occurred in 5-10\% patients in all type of the breast cancer(Parikesit et al., 2020; Peshkin et al., 2010). Various microRNAs are also associated with the gene expression of BRCA2 and it is a feasible signature for biomarkers (Petrovic et al., 2017). For example, research on long noncoding RNA (lncRNA) MIAT (Myocardial Infarction Associated Transcript) showed that MIAT expression levels are increased in several types of cancers, including breast cancer. This same research (which included silencing MIAT using specific siRNAs) also showed that MIAT suppression induced the growth arrest and increased the basal apoptosis. It also increased the apoptotic response of breast cancer cells to a wide range of apoptotic stimuli (Wheeler et al., 2015). The interesting phenomenon is the overexpression of BRCA2 mRNA has been observed in breast cancer cell, and this information will serve as a basis for the drug lead design (Surveillance Epidemiology and End Results Program, 2019). Moreover, Computer-Aided Drug Design (CADD)-based tools are currently applied in biomedical 
research (Valeska et al., 2019). Thus, cancer omics is the field that within the focus of the CADD application in bio medics domain (Anurogo et al., 2019). In the future, this research might be used to develop new transcriptomic-based drugs for cancers, including breast cancer. The utilization of silencing siRNAs as blocker of oncogenic genes have been proceeded to the clinical trials, and some have been marketed but for breast cancer it is still very scarce (Zaleska, 2015). These drugs might help to enhance the effectiveness of cancer therapy (Burnett and Rossi, 2012). This research would eventually block the progression of the mRNA expression of the BRCA2 with siRNA before it is expressed as protein. The objective of this research is to discover a possible RNA-based drug candidate for breast cancer using CADD-based specific transcriptomics tools with 2D and 3D molecular simulation approach. The notable similar work in this area is the development of the prediction pipeline for cervical cancer biomarkers albeit the works are limited to the proteomics-based molecular docking and the absence of transcriptomics-based docking pipeline(Arifin et al., 2020; Parikesit et al., 2018b). Moreover, regarding this research, a specific scoring function and molecular simulation methods for RNA molecules have been established accordingly(Hashem and Auffinger, 2009; McDowell et al., 2007; Šponer et al., 2018).

\section{Materials and Method}

The pipeline of this research was inspired from the previously published method that employ CADD-based approach from structural bioinformatics studies (Arifin et al., 2020; Parikesit, 2018). The BRCA2 breast cancer genes were downloaded from the NCBI website (https://www.ncbi.nlm.nih.gov/) in the FASTA format. Moreover, the Vienna RNA package (http://rna.tbi.univie.ac.at/) was employed to predict and annotate the 2D structure of the BRCA2 RNA (Gruber et al., 2008; TBI, 2016). On those websites, several online tools/applications (called "servers") that are related to the secondary and tertiary structures of RNA could be found. The first server that would be used is the RNAfold server (Lorenz et al., 2011). This server is used for predicting the minimum free energy structures and base pair probabilities from a single RNA or DNA sequences. The RNAfold server will be employed in order to find the most probable secondary structure/shape of the breast cancer gene.

The output of the application will be the 2D structures annotations in the Vienna dot bracket format. Thus, the modeRNA application

(http://iimcb.genesilico.pl/modernaserver/) was employed to predict the 3D structure of the RNA, with the PDB files as the output (Rother et al., 2011). The last step will be observing the molecular interactions between the RNA and its respective siRNA with

ClusPro

(https://cluspro.bu.edu/login.php) (Kozakov et al., 2017). The docking protocol was validated for RMSD less than $2 \AA$. All programs were using the default parameters as mentioned in the documentations.

\section{Result and Discussion}

Figure 1 shows the optimal secondary structure of the BRCA2 gene (Taken from the NCBI websites with the accession code of NM_000059.4 in the mRNA section). The optimal secondary structure is the structure that has the lowest minimum free energy. In this case, the optimal secondary structure of the BRCA2 gene has a minimum free energy of $-303.20 \mathrm{kcal} / \mathrm{mol}$. This simplified secondary structure diagram is saved in a dot-bracket notation. As seen in the figure 1, the mRNA structure of the BRCA2 is considered complex with several loops and bulges, and could be considered a transition state in a biochemical reaction. It is due to the unstable nature of the RNA molecule that 
hanged upon the free hydroxyl group in its backbone. This condition facilitates autocatalytic reaction that could destabilize the RNA molecule accordingly(Davis, 1998; Eigen et al., 1988).

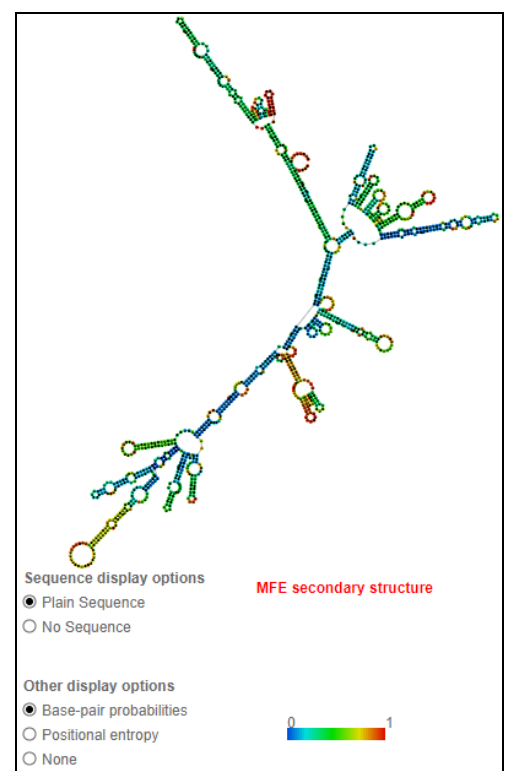

Figure 1. The diagram of the optimal secondary structure of BRCA2. The colors showed the base-pair probabilities of each base; red stands for high probability and dark blue stands for low probability.

Then, the RNAxs server was utilized (Tafer et al., 2008). This server will design the siRNAs (small interfering RNAs) of a certain gene, in this case the overexpressed BRCA2. The mRNA sequence of the BRCA2 gene in the FASTA format was uploaded to the RNAxs server, and the default parameters were employed accordingly. The result could be seen in the Figure 2. Here, an accessibility plot of the target sequence (a portion of the BRCA2 gene) and the siRNA molecule could be observed. The result showed the three best siRNA molecules for this BRCA2 gene (Figure 2). The first siRNA sequence is the only one needed, as it is the most thermodynamically feasible, and the proof of submission is notified in the Figure 2a. Based on the accessibility plot in the Figure $2 b$, it tends to shift away from 1, toward the value of 0 . It means that there is a huge possibility that the siRNA will attach to the designated target. It means that the siRNA would be able to repress the coding sequence accordingly. In the Figure 2c, the most feasible siRNA sequence is highlighted in the black box, and it is considered as the most favorable siRNA in the prediction system.
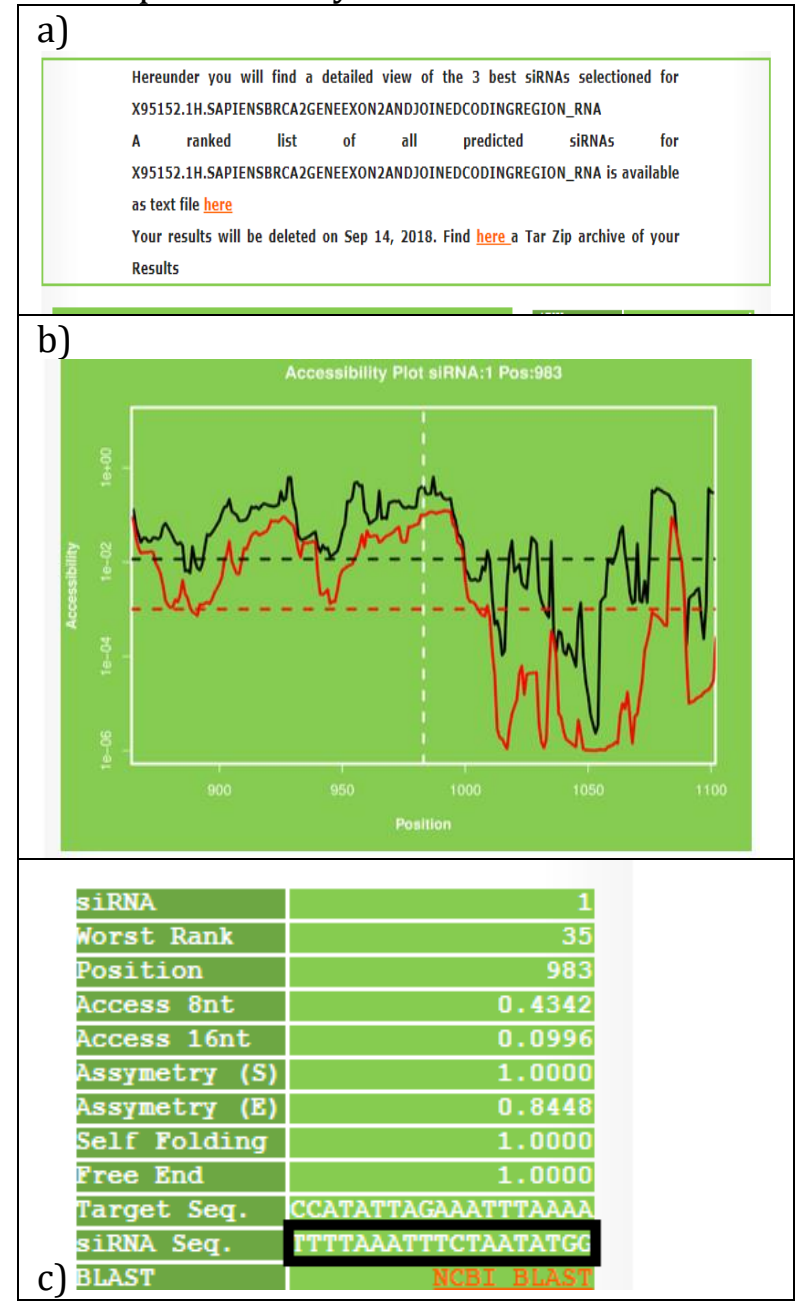

Figure 2. The siRNA result of BRCA2. Figure 2 (a) is the system notification of sequence acceptance Figure (2b): The black graph shows the accessibility of the target sequence and the red graph shows the accessibility of the siRNA sequence. Figure (2c) is the siRNA sequence output. 
Next, the Barriers server was applied to show the folding kinetics of the siRNA molecule (Flamm et al., 2002; Wolfinger et al., 2004). In order to use this server, it simply needs to paste the siRNA sequence into the text box and click "Proceed". Figure 3 showed the output of the program in form of the animation of the structural changes of the BRCA2 siRNA as it is progressing from a least stable folded conformation until the stable unfolded one.

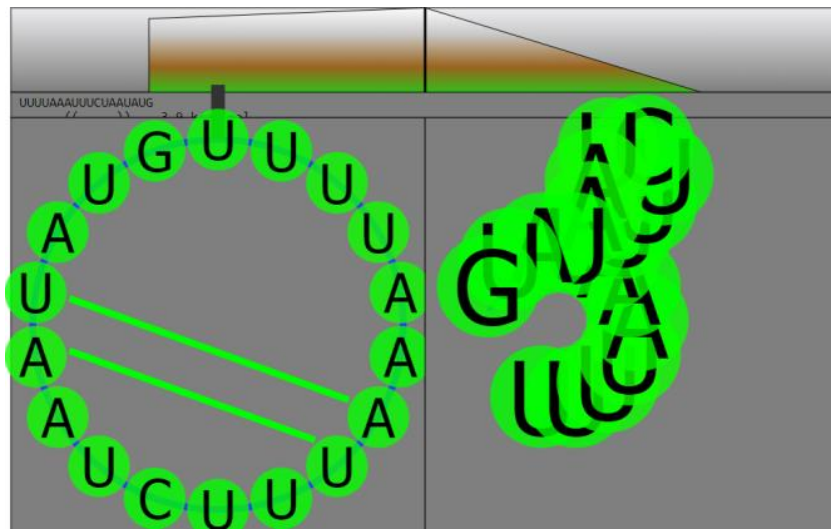

Figure 3. Barriers server result on BRCA2 siRNA.

The graph at the top shows the probability of structure formation. On the left side is the graph theory representation of the siRNA sequence and the predicted shape is on the right. The left side will animate the sequence graph, by relating each node with related edges. While the right side of the figure would show the animated folding of the RNA.

ModeRNA was employed to predict the three-dimensional tertiary structure of the BRCA2 gene and its siRNA. The server will show the 3D prediction result that is linked to the PDB ID. When the PDB ID is clicked, it will automatically be redirected to a page in the PDB's (Protein Data Bank) website ( http://www.rcsb.org) that shows the 3D structure of the target sequence (BRCA2) (PDB ID: 1J1U)
After the PDB files of the 3D structures of both the BRCA2 and the siRNA sequences were obtained, the ClusPro web server (https://cluspro.org/home.php) will be accessed to observe the docking configurations for the RNA sequences. ClusPro would show how the BRCA gene might bind to its siRNA molecule. The best conformation is the picture under ' 0 ' annotation as it is the most thermodynamically favorable one. As the docking RMSD has RMSD less than $2 \AA$. Value, In this regard, the docking protocol has shown that the overexpression of the BRCA2 genes in the breast cancer cell could be swiftly inhibited with its respective siRNA (Figure 4).

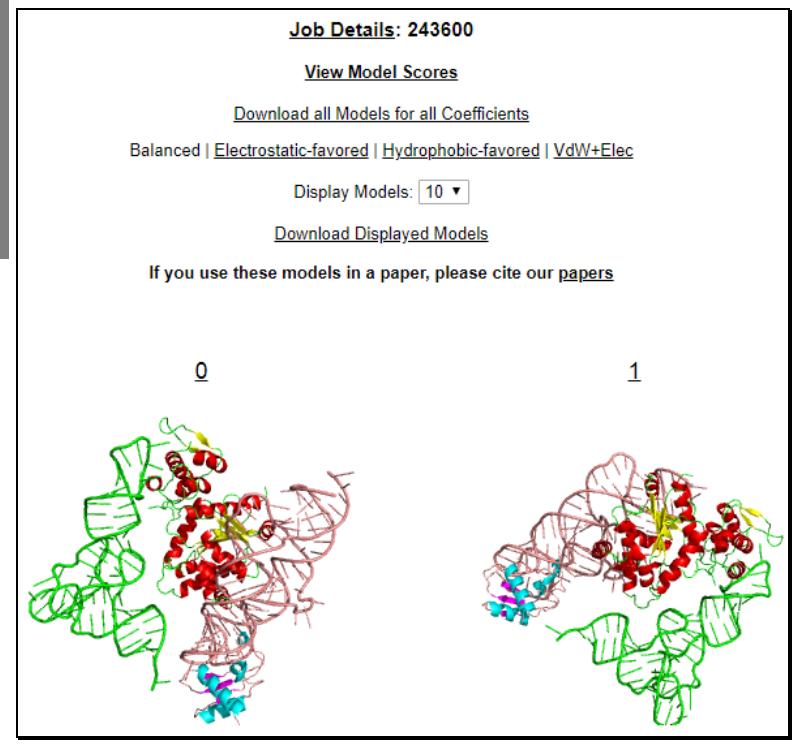

Figure 4. ModeRNA RNA 3D models were computed in the Cluspro server. The result shows the possible docking configurations BRCA2 RNA with its siRNA. The pink molecule is the BRCA2 molecule, while the green one is the siRNA molecule. 


\section{Conclusion and Suggestion}

Conclusion

The utilization of the 2D and 3D prediction of RNA structure scould be employed in swift manner. It is concluded that the BRCA2 siRNA-based drug design could be elucidated with determined bioinformatics tools as shown by the docking result.

Suggestion

In order to provide a stability examination of the mRNA-siRNA complex, molecular dynamics simulation should be conducted.

\section{Acknowledgments}

The authors would like to thank to Institute for Research and Community Services (LPPM) of Indonesia International Institute for Life Sciences (i3l) for their heartfelt support. Thanks also goes to Direktorat Riset dan Pengabdian Masyarakat, Direktorat Jenderal Penguatan Riset dan Pengembangan Kementerian Riset, Teknologi dan Pendidikan Tinggi Republik Indonesia for providing Hibah Penelitian Dasar DIKTI/LLDIKTI III 2019 No. 1/AKM/PNT/2019. The authors declare that there is no competing interest.

\section{References}

Anurogo, D., Parikesit, A.A., Ikrar, T., 2019. LncRNAs in CONDBITs Perspectives, From Genetics towards Theranostics. J. Sains Kesihat. Malaysia 17, 1-16. https://doi.org/10.17576/jskm-20191702-01

Arifin, M.Z., Agustriawan, D., Parikesit, A.A.P., 2020. Molecular simulation oF MDM2 and E6AP proteins as $\mathrm{P} 53$ regulator in cervical cancer. Biointerface Res. Appl. Chem. 10, 5875-5879. https://doi.org/10.33263/BRIAC104.8 75879
Bonofiglio, D., Giordano, C., De Amicis, F., Lanzino, M., Andò, S., 2016. Natural Products as Promising Antitumoral Agents in Breast Cancer: Mechanisms of Action and Molecular Targets. MiniReviews Med. Chem. 16, 596-604. https://doi.org/10.2174/13895575156 66150709110959

Burnett, J.C., Rossi, J.J., 2012. RNA-based therapeutics: current progress and future prospects. Chem. Biol. 19, 60-71. https://doi.org/10.1016/j.chembiol.20 11.12.008

Cherigo, L., Lopez, D., Martinez-Luis, S., 2015. Marine natural products as breast cancer resistance protein inhibitors. Mar. Drugs. https://doi.org/10.3390/md13042010

Cleator, S., Heller, W., Coombes, R.C., 2007. Triple-negative breast cancer: therapeutic options. Lancet Oncol. 8, 235-244. https://doi.org/10.1016/S14702045(07)70074-8

Davis, B.K., 1998. The forces driving molecular evolution. Prog. Biophys. Mol. Biol. 69, 83-150. https://doi.org/10.1016/S00796107(97)00034-5

Eigen, M., McCaskill, J., Schuster, P., 1988. Molecular quasi-species. J. Phys. Chem. 92, 6881-6891. https://doi.org/10.1021/j100335a010

Flamm, C., Hofacker, I.L., Stadler, P.F., Wolfinger, T., Wolfinger, M.T., 2002. Barrier Trees of Degenerate Landscapes. Zeitschrift für Phys. Chemie 216, 155. https://doi.org/10.1524/zpch.2002.21 6.2 .155

Goncalves, R., Warner, W.A., Luo, J., Ellis, M.J., 2014. New concepts in breast cancer genomics and genetics. Breast Cancer Res. https://doi.org/10.1186/s13058014-0460-4 
Gruber, A.R., Lorenz, R., Bernhart, S.H., Neuböck, R., Hofacker, I.L., 2008. The Vienna RNA websuite. Nucleic Acids Res. 36. https://doi.org/10.1093/nar/gkn188

Hashem, Y., Auffinger, P., 2009. A short guide for molecular dynamics simulations of RNA systems. Methods 47, 187-197. https://doi.org/10.1016/j.ymeth.2008. 09.020

Hedau, S., Batra, M., Singh, U., Bharti, A., Ray, A., Das, B., 2015. Expression of BRCA1 and BRCA2 proteins and their correlation with clinical staging in breast cancer. J. Cancer Res. Ther. https://doi.org/10.4103/09731482.140985

Kozakov, D., Hall, D.R., Xia, B., Porter, K.A., Padhorny, D., Yueh, C., Beglov, D., Vajda, S., 2017. The ClusPro web server for protein-protein docking. Nat. Protoc. https://doi.org/10.1038/nprot.2016.16 9

Lorenz, R., Bernhart, S.H., Höner zu Siederdissen, C., Tafer, H., Flamm, C., Stadler, P.F., Hofacker, I.L., 2011. ViennaRNA Package 2.0. Algorithms Mol. Biol. 6, 26. https://doi.org/10.1186/1748-7188-626

McDowell, S.E., Spacková, N., Sponer, J., Walter, N.G., 2007. Molecular dynamics simulations of RNA: an in silico single molecule approach. Biopolymers 85 , 169-84. https://doi.org/10.1002/bip.20620

Parikesit, A.A., 2018. The Construction of Two and Three Dimensional Molecular Models for the miR-31 and Its Silencer as the Triple Negative Breast Cancer Biomarkers. Online J. Biol. Sci. 18, 424431. https://doi.org/10.3844/ojbsci.2018.4 24.431

Parikesit, A.A., Agustriawan, D., Nurdiansyah,
R., 2020. Protein Annotation of Breastcancer-related Proteins with Machinelearning Tools. Makara J. Sci. 24, 6. https://doi.org/10.7454/mss.v24i1.12 106

Parikesit, A.A., Agustriawan, D., Nurdiansyah, R., 2018a. Telaah Sistematis Diagnosis dan Pengobatan Kanker Payudara Berbasis Transkriptomik, in: PROSIDING SEMINAR NASIONAL BIOLOGI 2018. FMIPA UNESA, Surabaya, pp. 438-443.

Parikesit, A.A., Utomo, D.H., Karimah, N., 2018b. Determination of secondary and tertiary structures of cervical cancer lncRNA diagnostic and siRNA therapeutic biomarkers. Indones. J. Biotechnol. 23, 1. https://doi.org/10.22146/ijbiotech.285 08

Peshkin, B.N., Alabek, M.L., Isaacs, C., 2010. BRCA1/2 mutations and triple negative breast cancers. Breast Dis. 32, 25-33. https://doi.org/10.3233/BD-20100306

Petrovic, N., Davidovic, R., Bajic, V., Obradovic, M., Isenovic, R.E., 2017. MicroRNA in breast cancer: The association with BRCA1/2. Cancer Biomarkers. https://doi.org/10.3233/CBM-160319

Rother, M., Milanowska, K., Puton, T., Jeleniewicz, J., Rother, K., Bujnicki, J.M., 2011. ModeRNA server: an online tool for modeling RNA 3D structures. Bioinformatics 27, 2441-2442. https://doi.org/10.1093/bioinformatic s/btr400

Spicer, J., 2005. Technology evaluation: nimotuzumab, the Center of Molecular Immunology/YM BioSciences/Oncoscience. Curr. Opin. Mol. Ther. 7, 182-91. 
Šponer, J., Bussi, G., Krepl, M., Banáš, P., Bottaro, S., Cunha, R.A., Gil-Ley, A., Pinamonti, G., Poblete, S., Jurečka, P., Walter, N.G., Otyepka, M., 2018. RNA Structural Dynamics As Captured by Molecular Simulations: A Comprehensive Overview. Chem. Rev. 118, 4177-4338. https://doi.org/10.1021/acs.chemrev.7 b00427

Surveillance Epidemiology and End Results Program, 2019. Cancer Stat Facts: Female Breast Cancer. Natl. Cancer Inst. 1-10.

Tafer, H., Ameres, S.L., Obernosterer, G., Gebeshuber, C.A., Schroeder, R., Martinez, J., Hofacker, I.L., 2008. The impact of target site accessibility on the design of effective siRNAs. Nat. Biotechnol. 26, 578-83. https://doi.org/10.1038/nbt1404

TBI, 2016. Vienna RNA Package Web Version 2.0 [WWW Document]. URL http://rna.tbi.univie.ac.at/\#intro

Valeska, M.D., Adisurja, G.P., Bernard, S., Wijaya, R., Aldino, M., Parikesit, A.A., 2019. The Role of Bioinformatics in Personalized Medicine: Your Future Medical Treatment. Cermin Dunia Kedokt. 46, 785-788.

Wheeler, N.J., Agbedanu, P.N., Kimber, M.J., Ribeiro, Paula, Day, T.A., Zamanian, M., Werf, M., Vlas, S., Brooker, S., Looman, C., Nagelkerke, N., Habbema, J., Engels, D., Murray, C., Vos, T., Lozano, R., Naghavi, M., Flaxman, A., Michaud, C., Wang, W., Wang, L., Liang, Y.-S., Gilbert, I., Chen, B., Wen, J.-F., Scimone, M., Kravarik, K., Lapan, S., Reddien, P, Zhang, J., Yuan, Z., Zheng, M., Sun, Y., Wang, Y., Yang, S., Evans, D., Owlarn, S., Romero, B.T., Chen, C., Aboobaker, A., Reddien, PW, Bermange, A., Murfitt, K., Jennings, J., Alvarado, A.S., Collins, J., Hou, X., Romanova, E., Lambrus, B., Miller, C., Saberi, A., Sweedler, J.,
Newmark, P, Gilleard, J., Robb, S., Ross, E., Sa, A., Abril, J., Cebri'a, F., RodrıguezEsteban, G., Horn, T., Fraguas, S., Calvo, B., Bartscherer, K., Sal'o, E., Galloni, M., Resch, A., Palakodeti, D., Lu, Y.-C., Horowitz, M., Graveley, B., Solana, J., Kao, D., Mihaylova, Y., Jaber-Hijazi, F., Malla, S., Wilson, R., Aboobaker, A., Nishimura, O., Hirao, Y., Tarui, H., Agata, K., Garcia-Fernandez, J., Ram, J., Marany, G., Mun, A., Kreshchenko, N., Pag'an, O., Deats, S., Baker, D., Montgomery, E., Wilk, G., Tenaglia, M., Semon, J., Ramakrishnan, L., Amatya, C., DeSaer, C., Dalhoff, Z., Eggerichs, M., Magoč, T., Salzberg, S., Grabherr, M., Haas, B., Yassour, M., Zerbino, D., Birney, E., Schulz, M., Zerbino, D., Vingron, M., Birney, E., Langmead, B., Trapnell, C., Pop, M., Salzberg, S., Li, B., Dewey, C., Li, W., Godzik, A., Conesa, A., G'otz, S., Garc'ia-G'omez, J., Terol, J., Tal'on, M., Robles, M., Lechner, M., Findeiss, S., Steiner, L., Marz, M., Stadler, P., Prohaska, S., Logan-Klumpler, F., Silva, N., Boehme, U., Rogers, M., Velarde, G., McQuillan, J., Carver, T., Aslett, M., Olsen, C., Subramanian, S., Phan, I., Farris, C., Mitra, S., Ramasamy, G., Wang, H., Tivey, A., Jackson, A., Houston, R., Parkhill, J., Holden, M., Harb, O., Brunk, B., Myler, P., Roos, D., Carrington, M., Smith, D., Hertz-Fowler, C., Berriman, M., Krzywinski, M., Schein, J., Birol, I., Connors, J., Gascoyne, R., Horsman, D., Jones, S., Marra, M., Camacho, C., Coulouris, G., Avagyan, V., Ma, N., Papadopoulos, J., Bealer, K., Madden, T., Pruitt, K., Brown, G., Hiatt, S., Thibaud-Nissen, F., Astashyn, A., Ermolaeva, O., Farrell, C., Hart, J., Landrum, M., McGarvey, K., Murphy, M., Rask-Andersen, M., Alm'en, M., Schïoth, H., Milligan, J., Jolly, E., Schneider, C., Rasband, W., Eliceiri, K., Noldus, L., Spink, A., Tegelenbosch, R., Koressaar, T., Remm, M., Rouhana, L., Weiss, J., Forsthoefel, D., Lee, H., King, R., Inoue, 
T., Shibata, N., Agata, K., Newmark, P, Kao, D., Felix, D., Aboobaker, A., Patocka, N., Ribeiro, P, Jones, P., Binns, D., Chang, H.-Y., Fraser, M., Li, W., McAnulla, C., McWilliam, H., Maslen, J., Mitchell, A., Nuka, G., Pesseat, S., Quinn, A., Sangrador-Vegas, A., Scheremetjew, M., Yong, S.-Y., Lopez, R., Hunter, S., Kanehisa, M., Goto, S., Sato, Y., Kawashima, M., Furumichi, M., Tanabe, M., Hetrick, B., Han, M., Helgeson, L., Nolen, B., Nogi, T., Zhang, D., Chan, J., Marchant, J., Crowther, G., Shanmugam, D., Carmona, S., Doyle, M., Hertz-Fowler, C., Berriman, M., Nwaka, S., Wang, B., Collins, J., Newmark, PA, 2015.

Functional analysis of Girardia tigrina transcriptome seeds pipeline for anthelmintic target discovery. Parasit. Vectors 8, 34.

https://doi.org/10.1186/s13071-0140622-3

WHO, 2015. WHO | Breast cancer: prevention and control [WWW Document]. WHO. URL https://www.who.int/cancer/detection /breastcancer/en/

Wolfinger, M.T., Svrcek-Seiler, W.A., Flamm, C., Hofacker, I.L., Stadler, P.F., 2004. Efficient computation of RNA folding dynamics. J. Phys. A. Math. Gen. 37, 4731-4741. https://doi.org/10.1088/03054470/37/17/005

Wu, D., Rice, C.M., Wang, X., 2012. Cancer bioinformatics: A new approach to systems clinical medicine. BMC Bioinformatics. https://doi.org/10.1186/1471-210513-71

Zaleska, K., 2015. MiRNA - Therapeutic tool in breast cancer? Where are we now? Reports Pract. Oncol. Radiother. https://doi.org/10.1016/j.rpor.2014.10 .009 